\title{
Women's rugby league injury claims and costs in New Zealand
}

\author{
D A King, ${ }^{1,2}$ P A Hume, ${ }^{2}$ P Milburn, ${ }^{3}$ S Gianotti2,4
}

${ }^{1}$ Emergency Department, Hutt Valley District Health Board, Lower Hutt, New Zealand ${ }^{2}$ Institute of Sports and Recreation Research New Zealand, School of Sport and Recreation, Faculty of Health and Environmental Science, Auckland University of Technology, Auckland, New Zealand

${ }^{3}$ School of Physiotherapy \& Exercise Science, Griffith University, Gold Coast, Queensland, Australia

${ }^{4}$ Accident Compensation Corporation, Wellington, New Zealand

\section{Correspondence to}

Doug A King, Emergency Department, Hutt Valley District Health Board Private Bag 31-907, Lower Hutt, New Zealand; douglas.king@huttvalleydhb. org.nz

Accepted 3 October 2009

\section{ABSTRACT}

Aim There is scarce information on rugby league injuries in female players. This paper provides an overview of the epidemiology of women's rugby league injuries requiring medical treatment and associated costs in New Zealand.

Method New Zealand Accident Compensation Corporation injury data for the period 1999-2007 were searched for rugby league injury cases occurring in females. Data were analysed by demographics, body region, nature/severity of injury, and medical procedure and costs.

Results There were 320 moderate to serious injury claims recorded for females participating in rugby league activities over the study period. There was a mean (SD) of 37.9 (9.5) injury claims per year. The mean cost per year for the study period was \$196 514 (\$99 133) (£76 066 (£38 374)) with half of the injury claims occurring in New Zealand Maori. Concussion/brain injuries accounted for $3.8 \%$ of total female moderate to serious injury claims but accounted for $5.4 \%$ of female injury costs (\$84 399 (£32 688)) with the highest mean cost per claim (\$7033 (£2724)). The lower limb accounted for $65 \%$ of the total female injury claims and $58.7 \%$ of total injury costs (\$922 296 (£356 968)). The mean cost per claim was higher for the lower limb (\$4434 (f1714)) than the upper (\$3331 (£1288)) limb. Clerks recorded $16.3 \%$ of the total injury claims, $20.3 \%$ of total injury costs (\$319 474 (£123 211)) and had the highest mean cost per claim ( $\$ 6144$ (£2370)). The 25-29 age group recorded $31.9 \%$ of injury claims and $33.8 \%$ of injury costs. The 35-39 age group recorded the highest mean cost per claim (\$6200 (£2392)) but only $10.9 \%$ of total claims and $13.8 \%$ of total costs.

Discussion When compared with other studies in rugby league injuries, it appears that females incur substantially fewer injuries (5.7\%) than males (94.3\%). Although no participation data by sex are available, it is likely that participation percentages are reflected in the injury percentages. The high frequency $(65 \%)$ and cost proportion (58.7\%) for lower limb injuries was higher in females than in male rugby league players (previously reported as $42.4 \%$ of the injury claims and $31.5 \%$ of the total injury claim costs for the lower limb).

Conclusions Injury prevention programmes for women's rugby league should focus on the 25-29 age group and address ways to prevent concussion and lower limb injuries.

Beginning from the its early origins in the north of England in the 1890s, ${ }^{1}$ the game of rugby league has become an internationally participated collision sport ${ }^{1-3}$ played at elite, semielite, amateur and junior levels. ${ }^{124}$ Rugby league requires the participants to undergo repetitive physical collisions and tackles. ${ }^{5-7}$ During an 80 -min game, the ball is in play for an average of $50 \mathrm{~min},{ }^{8}$ with each player being involved in between 20 and 40 tackles per game $^{8}$ and covering between 7000 and $10000 \mathrm{~m} .{ }^{9}$ As a result of these physical collisions, musculoskeletal injuries occur frequently. ${ }^{3-5}$

Although the most common rugby league participant is male, female participation in rugby league does occur. ${ }^{10}$ The first recorded women's rugby league match was played in Sydney, Australia, on 17 September 1921. ${ }^{11}$ It was described as a "freak show" because it was seen to be a threat to the masculine underpinnings of the game, but 25000 people were reported to watch the match between the established Sydney and Metropolitan teams. ${ }^{11}$ Yet despite positive reports about the spectacle of women's rugby league, players were ridiculed and attempts to establish the game were sporadic and often floundered. ${ }^{11}$ It was not until 1990s that women's rugby league became firmly established international amateur participation sport. ${ }^{11}$

Studies have demonstrated the nature and incidence of injuries in rugby league when played by males $^{1-8}$ and that the incidence of injury typically increases as the participation level increases. The rugby league injury rates vary for senior (amateur, semielite, elite $)^{1} 24$ and junior ${ }^{12} 13$ participants with elite players typically having a higher injury incidence in most, ${ }^{13}$ but not all, ${ }^{14}$ published studies. When reporting injuries resulting in missed matches only, the rate varies from $26.8^{15}$ to $67.7^{14}$ per 1000 playing hours but when considering all injuries (including transient injuries), the incidence varies from $58.4^{16}$ to $824.7^{14}$ per 1000 playing hours depending on the injury definition used. ${ }^{17}$

However, there is a paucity of data to indicate the nature of injuries sustained by females playing rugby league, with a review of the literature showing only two published studies. ${ }^{10} 18$ One study ${ }^{10}$ reviewed the anthropometric and physiological perspectives of elite women's rugby league participants, whereas the other reported the incidence of injuries at a women's rugby league tournament. ${ }^{18}$ No other studies appear to have been published on women's rugby league despite there being domestic, national and international competitions played.

An epidemiological overview of rugby league injuries and the associated injury costs has previously been undertaken. ${ }^{19}$ This study combined both male and female injury claims but did not differentiate them in its analysis. This current paper builds on the initial work by providing further analysis of the women's injury data with the aim of enhancing understanding of injuries that occur in women's rugby league to help develop injury reduction programs specifically targeted 
at female participants. With this mind, the goal of this paper was to provide an epidemiological overview of female rugby league injuries in one country (New Zealand) over 8 years. New Zealand's no-fault injury compensation system administered by the Accident Compensation Corporation (ACC) means that New Zealand is uniquely positioned to provide detailed descriptive epidemiological data including costs associated with treatment on female rugby league participants. Using these data, a comparison of the rate, site, type, occupation, age and location of female rugby league injuries was conducted.

\section{METHODS}

ACC cover is available to any person, including visitors to New Zealand that has accidental personal injury at any time when in New Zealand. People who have a personal injury can make a claim to ACC at the time of seeking medical treatment from $>30000$ registered health professionals throughout the country. When making a claim, information about the injury is collected using a standard ACC 45 injury reporting form to ensure levels of consistency for data recording and analyses. The injured person (unless impaired) completes information about the activity surrounding the injury (eg, location, activity prior, cause, narrative) along with their personal details (eg, age, sex, ethnicity, contact details). The registered health professional completes the form by providing information regarding initial diagnosis and other relevant medical information (eg, surgical procedure). The claim is then filed with ACC and details are entered into a central database.

ACC has no disincentive for making claims nor are people risk-rated or penalised for the number of claims they make. ${ }^{20}$ Personal injury coverage is guaranteed by ACC, but this is offset by the restriction to sue for personal injury except in rare circumstances for exemplary damages. ${ }^{20}$ ACC categorises the claims made as minor or moderate to serious claims (MSCs) and as new or ongoing injury claims. Minor injury claims reflect those injuries that require the initial medical treatment or service and may only require one or two visits to a health professional. MSCs reflect those injuries that require additional treatment than the initial medical treatment or service-for example, income replacement if the injury requires more than five consecutive days off work. Serious injury claims are permanent brain injury or spinal damage. New claims are those made in the reporting period and are reflective of the number of new injuries from rugby league participation. Ongoing injury claims are reflective of the severity of the injury claim and can carry on over the reporting period. In this study, MSCs are reported with new and ongoing injuries combined per reporting period.

Throughout the study period, there were 42754 rugby league claims costing the ACC \$48704704 (£18 099 470). Female MSCs represented only $0.7 \%$ (320) of the number of total rugby league claims and 3.2\% (\$1 572110 (£614 787)) of the total rugby league injury entitlement costs. For this review we focused on MSCs rather than on minor rugby league claims as defined by the ACC for its sports cost outcome model, ${ }^{20}$ which occurred between 1 July 1999 and 30 June 2007 as a result of participating in rugby league activities.

Because there were no reliable rugby league participation data collected by New Zealand Rugby League, New Zealand population data were obtained from official government sources. This data set provides estimates of resident populations between each 5 -year census. ${ }^{21}$ The population of New Zealand over the study period was approximately 4.1 million people based on the 2006 Census $^{21}$ and the proportion of females in the population in 2006 was $51.2 \%$ (2.1 million).

ACC data were analysed by various categories: (1) injury site, (2) injury type, (3) age and (4) region/district and occupational classification (see table 1). ${ }^{22}$

\section{Ethical consent}

Ethical consent for the research was obtained from the Auckland University of Technology Ethics Committee. Informed consent from the injured participants was not obtained because data were collected from the ACC database without individual player follow-up.

\section{Data limitations}

Epidemiological studies are dependent on data quality for any analysis to be undertaken. ${ }^{23}$ The data provided for the analysis in this study are from the ACC database and are dependent on several factors: (1) the correct data code was on the data collection sheet; (2) the occupational classifications provided are limited to just 10 classifications as identified by the New Zealand Standard Classifications of Occupations. ${ }^{22}$ Although there are subclassifications under this standard, these are not recorded in the data input process. (3) The occupational classification is open for interpretation by the data operator at the data input stage, that is, a program manager can be classified as a professional, technical or administrator, whereas they may be a program manager for a trade worker, computer operator or elementary occupation. (4) People going to a registered health professional for treatment of their injury; (5) underreporting of costs because of patients undertaking private medical care; and (6) people making a claim for the injury (there is no time limit on when a patient can make an acute injury claim to ACC). ${ }^{23}$ The data retrieved are protected to ensure client confidentiality by limiting the access to low-level results under four injury claims. Therefore, any data less than or equal to three injury claims has been rounded to represent three claims only. The net result of these limitations may see a downwards bias in the injury entitlement claim incidence and some of the calculations will not be equal depending on the way the data was rounded.

\section{Statistical analyses}

All the data collected were entered into a Microsoft Excel spreadsheet and analysed with SPSS V.16.0 (SPSS, Chicago, Illinois, USA). Injury rates were calculated as the number of injuries per 1000 rugby league injury claims. ${ }^{24}$ Data are reported as means and SD and with 95\% confidence intervals (CIs) where appropriate. ${ }^{25}$ The injury rates and patterns were compared between reporting years using a one-sample $\chi^{2}$ test. Significant $p$ values reported in the text are $<0.001$ if they are not specifically stated. Injury incidence was not calculated for the study because rugby league participation rates were not available as part of the data analysis. All costs are reported in New Zealand dollars (\$) and UK pounds $(£)$ unless otherwise indicated.

\section{RESULTS}

Over the period July 1999 to June 2007, there were 320 MSCs recorded for females participating in rugby league activities (see table 2). The mean cost per MSC was $\$ 4913$ (£1872) from a mean (SD) of 37.9 (9.5) injury claims per year. The mean cost per year for the study period was \$196514 (\$99 133) (£76 066 (£38 374)). Initially, the and costs decreased (claims: $10.7 \%$ (2.8\%); costs $8.5 \%(2.9 \%)$ ) peryear over the $1999-2000$ to $2001-$ 2002 reporting periods, but over the 2002-2003 to 2006-2007 
Table 1 Data categories analysed

\begin{tabular}{|c|c|c|c|c|c|c|c|}
\hline \multirow{2}{*}{$\begin{array}{l}\text { Ethnicity } \\
\text { Group includes }\end{array}$} & \multicolumn{2}{|l|}{ Region } & \multicolumn{2}{|l|}{ Injury site } & \multirow[b]{2}{*}{ Injury type } & \multirow[b]{2}{*}{ Age in years } & \multirow{2}{*}{$\begin{array}{l}\text { Occupation } \\
\text { NZSCO } \text { categories }^{22}\end{array}$} \\
\hline & Area & District & Group & Subgroup & & & \\
\hline $\begin{array}{l}\text { New Zealand } \\
\text { European }\end{array}$ & $\begin{array}{l}\text { North } \\
\text { Island }\end{array}$ & & Head/neck & & Soft tissue injury & $5-9$ & $\begin{array}{l}\text { Legislators, administrators, } \\
\text { and managers }\end{array}$ \\
\hline New Zealand Maori & & Northland & & Head (except face) & Corrosive injuries & $10-14$ & Professionals \\
\hline Pacific Peoples & & Auckland & & Face & Dental injuries & $15-19$ & $\begin{array}{l}\text { Technicians and associate } \\
\text { professionals }\end{array}$ \\
\hline Cook Island Maori & & Waikato & & Eye & Fracture/dislocation & $20-24$ & Clerks \\
\hline Tongan & & Bay of Plenty & & Nose & Hernia & $25-29$ & Service and sales workers \\
\hline Niuean & & Gisborne & & Ear & $\begin{array}{l}\text { Laceration, puncture, } \\
\text { wound, sting }\end{array}$ & $30-34$ & $\begin{array}{l}\text { Agriculture and fishery } \\
\text { workers }\end{array}$ \\
\hline Fijian & & Hawke's Bay & & $\begin{array}{l}\text { Neck/back of head/ } \\
\text { vertebrae }\end{array}$ & $\begin{array}{l}\text { Foreign body in } \\
\text { orifice/eye }\end{array}$ & $35-39$ & Trades workers \\
\hline Tokelauan & & Taranaki & Upper limb & & $\begin{array}{l}\text { Concussion/brain } \\
\text { injury }\end{array}$ & $40-44$ & $\begin{array}{l}\text { Plant and machine operators } \\
\text { and assemblers }\end{array}$ \\
\hline Other Pacific & & $\begin{array}{l}\text { Manaweatu- } \\
\text { Wanganui }\end{array}$ & & $\begin{array}{l}\text { Shoulder (including } \\
\text { clavicle/ } \\
\text { shoulder blade) }\end{array}$ & Amputation & $45-49$ & Elementary occupations \\
\hline Asian & & Wellington & & Upper and lower arm & Deafness & $50-54$ & Unknown \\
\hline South East Asian & $\begin{array}{l}\text { South } \\
\text { Island }\end{array}$ & & & Elbow & Other/unknown & $55-59$ & \\
\hline Indian & & Tasman & & Hand/wrist & & $60-64$ & \\
\hline \multirow[t]{15}{*}{ Other/unknown } & & Nelson & & Finger/thumb & & $65-69$ & \\
\hline & & Marlborough & Lower limb & & & $70-79$ & \\
\hline & & Canterbury & & Hip/upper leg/thigh & & $80+$ & \\
\hline & & West Coast & & Knee & & & \\
\hline & & Otago & & Lower limb & & & \\
\hline & & Southland & & Ankle & & & \\
\hline & $\begin{array}{l}\text { Other/ } \\
\text { unknown }\end{array}$ & & & Foot & & & \\
\hline & & & & Toes & & & \\
\hline & & & $\begin{array}{l}\text { Chest/back/ } \\
\text { other }\end{array}$ & & & & \\
\hline & & & & Abdomen/pelvis & & & \\
\hline & & & & Chest & & & \\
\hline & & & & Back/spine & & & \\
\hline & & & & Internal organ & & & \\
\hline & & & & Multiple locations & & & \\
\hline & & & Unknown & & & & \\
\hline
\end{tabular}

NZSCO, New Zealand Standard Classification of Occupations.

Table 2 Total injury rate per 1000 entitlement claims with $95 \% \mathrm{Cl}$ and percentage of total claims and differences by reporting year

\begin{tabular}{|c|c|c|c|c|c|c|c|c|c|c|c|}
\hline \multirow[b]{2}{*}{ Years } & \multicolumn{2}{|c|}{ Total female injury claims } & \multicolumn{3}{|c|}{ Total female injury costs } & \multicolumn{2}{|c|}{$\begin{array}{l}\text { Difference from previous } \\
\text { year for total injury claims }\end{array}$} & \multicolumn{2}{|c|}{$\begin{array}{l}\text { Difference from } 1999 \text { to } \\
2000 \text { for total injury claims }\end{array}$} & \multicolumn{2}{|c|}{$\begin{array}{l}\text { Difference from } 2002 \text { to } \\
2003 \text { for total injury claims }\end{array}$} \\
\hline & No. & Rate $(95 \% \mathrm{CI})$ & $\$(000)$ & $\%$ & Mean \$ & $\chi^{2}(\mathbf{d f}=1)$ & p Value & $\chi^{2}(\mathbf{d f}=1)$ & p Value & $\chi^{2}(\mathbf{d f}=1)$ & p Value \\
\hline $99-00$ & 44 & 137.5 (102.3 to 184.8 ) & 184 & 11.7 & 4179 & - & & - & & 1 & 0.169 \\
\hline $00-01$ & 33 & 103.1 (73.3 to 145.1$)$ & 123 & 7.8 & 3714 & 1 & 0.210 & 1 & 0.21 & 0.0 & 0.901 \\
\hline $01-02$ & 26 & 81.3 (55.3 to 119.3 ) & 96 & 6.1 & 3681 & 4 & 0.031 & 0.8 & 0.362 & 0.6 & 0.431 \\
\hline $02-03$ & 32 & $100.0(70.7$ to 141.4$)$ & 122 & 7.7 & 3796 & 1 & 0.169 & 0.6 & 0.431 & - & \\
\hline $03-04$ & 35 & 109.4 (78.5 to 152.3$)$ & 181 & 11.5 & 5167 & 1 & 0.311 & 0.1 & 0.714 & 0.1 & 0.714 \\
\hline $04-05$ & 55 & 171.9 (132.0 to 223.9$)$ & 276 & 17.5 & 5014 & 1 & 0.269 & 4 & 0.035 & 6 & 0.014 \\
\hline $05-06$ & 40 & 125.0 (91.7 to 170.4$)$ & 193 & 12.3 & 4833 & 0.2 & 0.663 & 2 & 0.124 & 0.8 & 0.346 \\
\hline $06-07$ & 55 & 171.9 (132.0 to 223.9$)$ & 399 & 25.4 & 7247 & 1 & 0.269 & 2 & 0.124 & 6 & 0.014 \\
\hline
\end{tabular}

Rates are per 1000 injury claims. Percentage totals do not equal $100 \%$ because of data rounding. Total injury costs, percentage of total costs and mean cost per claim by reporting year.

reporting periods, both the number and costs of injury claims increased (claims: $13.6 \%(3.4 \%)$; costs: $14.9 \%(6.8 \%)$ ) per year. There was no statistically significant difference observed in the decrease from 1999-2000 (137 per 1000 injury claims) to the 2001-2002 (81 per 1000 injury claims) reporting years (see table 2). However, there was a significant increase in the injury claims in 2006-2007 (171 per 1000 injury claims) compared to 2002-2003 (100 per 1000 injury claims).

\section{Female injury claims and costs by ethnic group}

Half of the female injury claims were recorded as being to New Zealand Maori (500 per 1000 injury claims; 50\%). New 
Zealand Maori also recorded nearly half of the injury costs (\$745 497 ( $£ 288605$ ); 47.4\%) (see table 3). There were significant differences observed between most, but not all, ethnic groups for the females over the study period, although there were no recorded female Asians participating in rugby league throughout the study period.

\section{Female injury claims and costs by district}

For female rugby league players, more injury claims were recorded in the North (943 per 1000 injury claims; 94.4\%) than the South Island (228 per 1000 injury claims; 22.8\%) $\left(\chi^{2}=139, \mathrm{df}=1\right)$ (see table 4$)$. More than three-quarters of the costs were for North Island-based players (\$1 214543 ( $£ 470373$ ); 77.3\%). Despite this, the highest mean cost per injury entitlement claim was recorded in the South Island (\$4606 (£1784) vs $\$ 4022$ (£1557)). In the North Island, the major metropolitan region of Auckland recorded more claims (478 per 1000 injury claims, 47.8\%) and costs (\$854 438 $(£ 330864))$ than other North Island districts $\left(\chi^{2}=501, \mathrm{df}=8\right)$. In the South Island, Canterbury recorded more claims (153 per 1000 injury claims, 15.3\%) and costs (\$305 142 (£118 160)) than other South Island districts $\left(\chi^{2}=156, \mathrm{df}=6\right)$. Canterbury also recorded the highest mean cost per injury claims (\$6227 (£2412)).

Table 3 Total injury rate per 1000 entitlement claims with $95 \% \mathrm{Cl}$ and percentage of total claims and differences per year by ethnicity 1999-2007

\begin{tabular}{|c|c|c|c|c|c|c|c|c|c|c|c|c|}
\hline \multirow{3}{*}{$\begin{array}{l}\text { Ethnic group } \\
\text { New Zealand } \\
\text { European }\end{array}$} & \multirow{3}{*}{$\begin{array}{l}\text { Total female injury claims } \\
\text { No. Rate (95\% CI) } \\
70218.8 \text { (173.1 to } 276.5)\end{array}$} & \multicolumn{3}{|c|}{ Total female injury costs } & \multirow{2}{*}{\multicolumn{2}{|c|}{$\begin{array}{l}\begin{array}{l}\text { Difference from } \\
\text { NZ European for } \\
\text { total injury claims }\end{array} \\
\chi^{2}(\mathrm{df}=1) \mathrm{p} \text { Value }\end{array}$}} & \multirow{2}{*}{\multicolumn{2}{|c|}{$\begin{array}{l}\text { Difference from } \\
\text { NZ Maori for total } \\
\text { injury claims } \\
\chi^{2}(\mathrm{df}=1) \text { p Value }\end{array}$}} & \multicolumn{2}{|c|}{$\begin{array}{l}\text { Difference from } \\
\text { Pacific Peoples } \\
\text { for total injury } \\
\text { claims }\end{array}$} & \multirow{2}{*}{\multicolumn{2}{|c|}{$\begin{array}{l}\begin{array}{l}\text { Difference from } \\
\text { other/unknown for } \\
\text { total injury claims }\end{array} \\
\chi^{2}(\mathrm{df}=1) \text { p Value }\end{array}$}} \\
\hline & & \multirow{2}{*}{$\begin{array}{l}\mathbf{( 0 0 0 )} \\
354\end{array}$} & \multirow{2}{*}{\begin{tabular}{l|l}
$\%$ \\
22.5
\end{tabular}} & \multirow{2}{*}{$\begin{array}{l}\text { Mean } \\
5059\end{array}$} & & & & & $\chi^{2}(\mathrm{df}=1)$ & p Value & & \\
\hline & & & & & - & & 30 & $<0.001$ & 2 & 0.097 & 6 & 0.011 \\
\hline $\begin{array}{l}\text { New Zealand } \\
\text { Maori }\end{array}$ & 160500.0 (428.2 to 583.8$)$ & 746 & 47.4 & 4659 & 30 & $<0.001$ & - & & 50 & $<0.001$ & 61 & $<0.001$ \\
\hline Asian & $0 \quad 0.0_{-}$ & - & 0 & - & 75 & $<0.001$ & 160 & $<0.001$ & 56 & $<0.001$ & 47 & $<0.001$ \\
\hline $\begin{array}{l}\text { Other/ } \\
\text { unknown }\end{array}$ & 39121.9 (89.0 to 166.8 ) & 211 & 13.4 & 5406 & 6 & 0.011 & 61 & $<0.001$ & 0.7 & 0.375 & - & \\
\hline
\end{tabular}

Rates are per 1000 injury claims. Percentage totals do not add to $100 \%$ because of rounding. Total injury costs, percentage of total costs and mean cost per claim by ethnic group 1999-2007.

Table 4 Total injury rate per 1000 entitlement claims with $95 \% \mathrm{Cl}$ and percentage of total claims and differences per year by district $1999-2007$

\begin{tabular}{|c|c|c|c|c|c|c|c|c|c|c|c|}
\hline & \multicolumn{2}{|c|}{ Total female injury claims } & \multicolumn{3}{|c|}{$\begin{array}{l}\text { Total female injury } \\
\text { costs }\end{array}$} & \multicolumn{2}{|c|}{$\begin{array}{l}\text { Difference over reporting } \\
\text { years for total injury } \\
\text { claims }\end{array}$} & \multicolumn{2}{|c|}{$\begin{array}{l}\text { Difference } 99-00 \text { and } \\
06-07 \text { for total injury } \\
\text { claims }\end{array}$} & \multicolumn{2}{|c|}{$\begin{array}{l}\text { Difference from Auckland } \\
\text { for total injury claims }\end{array}$} \\
\hline & No. & Rate $(95 \% \mathrm{CI})$ & $\$(000)$ & $\%$ & Mean \$ & $\chi^{2}(\mathbf{d f}=7)$ & p Value & $\chi^{2}(\mathrm{df}=1)$ & p Value & $\chi^{2}(\mathbf{d} \mathbf{f}=1)$ & p Value \\
\hline North Island total & 244 & 762.5 (672.6 to 864.4$)$ & 1215 & 77.3 & 4978 & 12 & 0.0769 & 0.9 & 0.3346 & - & \\
\hline Northland & 19 & 59.4 (37.9 to 93.1$)$ & 38 & 2.4 & 2005 & 16 & 0.019 & 0 & 1.0 & 104 & $<0.001$ \\
\hline Auckland & 153 & 478.1 (408.1 to 560.2 ) & 854 & 54.3 & 5585 & 12 & 0.098 & 0.6 & 0.405 & - & \\
\hline Waikato & 17 & 53.1 (85.1 to 100.6$)$ & 4263 & 10 & 7750 & 4 & 0.689 & 0.5 & 0.48 & 92 & $<0.001$ \\
\hline Bay of Plenty & 20 & $62.5(40.3$ to 96.9$)$ & 91 & 5.8 & 4562 & 2 & 0.925 & 0.1 & 0.706 & 82 & $<0.001$ \\
\hline Gisborne & 6 & 18.8 (8.4 to 41.7$)$ & 30 & 1.9 & 5033 & 9 & 0.253 & 3 & 0.083 & 113 & $<0.001$ \\
\hline Hawkes' Bay & 8 & $25.0(12.5$ to 50.0$)$ & 71 & 4.5 & 8902 & 10 & 0.189 & 0 & 1.0 & 111 & $<0.001$ \\
\hline Taranaki & 7 & 21.9 (10.4 to 45.9$)$ & 5 & 0.3 & 690 & 9 & 0.253 & 3 & 0.083 & 113 & $<0.001$ \\
\hline $\begin{array}{l}\text { Manawatu- } \\
\text { Wanganui }\end{array}$ & 4 & 12.5 (4.7 to 33.3$)$ & 26 & 1.6 & 6462 & 15 & 0.036 & 3 & 0.083 & 128 & $<0.001$ \\
\hline Wellington & 10 & $31.3(16.8$ to 58.1$)$ & 30 & 1.9 & 3001 & 8 & 0.333 & 5 & 0.025 & 0.2 & $<0.001$ \\
\hline
\end{tabular}

\begin{tabular}{|c|c|c|c|c|c|c|c|c|c|c|c|}
\hline & & & & & & & & & & \multicolumn{2}{|c|}{$\begin{array}{l}\text { Difference from Canterbury } \\
\text { for total injury claims }\end{array}$} \\
\hline & & & & & & & & & & $\chi^{2}(\mathbf{d} \mathbf{f}=1)$ & p Value \\
\hline South Island total & 64 & $200.0(156.5$ to 255.5$)$ & 336 & 21.4 & 5254 & 7 & 0.3741 & 1 & 0.2207 & - & \\
\hline Tasman & 0 & $0.0_{-}$ & - & 0 & - & 0 & 1.0 & 0 & 1.0 & 49 & $<0.001$ \\
\hline Nelson & 3 & 9.4 (3.0 to 29.1$)$ & 18 & 1.2 & 6097 & 6 & 0.509 & 0 & 1.0 & 27 & $<0.001$ \\
\hline Marlborough & 3 & $9.4(3.0$ to 29.1$)$ & $>1$ & 0 & 258 & 21 & 0.004 & 3 & 0.083 & 40 & $<0.001$ \\
\hline Canterbury & 49 & 153.1 (115.7 to 202.6 ) & 305 & 19.4 & 6227 & 4 & 0.734 & 0.6 & 0.439 & - & \\
\hline West Coast & 3 & 9.4 (3.0 to 29.1$)$ & 6 & 0.4 & 2091 & 18 & 0.012 & 3 & 0.083 & 33 & $<0.001$ \\
\hline Otago & 6 & 18.8 (8.4 to 41.7$)$ & 6 & 0.4 & 959 & 18 & 0.012 & 3 & 0.083 & 33 & $<0.001$ \\
\hline Southland & 0 & $0.0_{-}$ & - & 0 & - & 0 & 1.0 & 0 & 1.0 & 49 & $<0.001$ \\
\hline Other/unknown total & 12 & $37.5(21.3$ to 66.0$)$ & 21 & 1.4 & 1778 & 12 & 0.101 & 0 & 1.0 & & \\
\hline
\end{tabular}

\footnotetext{
Rates are per 1000 injury claims. Percentage totals do not equal $100 \%$ because of data rounding. Total injury costs, percentage of total costs and mean cost per claim by
} district 1999-2007. 


\section{Female injury claims and costs by injury type}

Soft tissue injuries were the most commonly claimed injury, whereas fracture dislocations were slightly less (see table 5). Concussion/brain injuries accounted for $3.8 \%$ of total female MSCs but accounted for $5.4 \%$ of costs ( $\$ 84399$ ( $£ 32688)$ ) and the highest mean cost per claim (\$7033 (£2724)).

\section{Female injury claims and costs by injury site}

There were differences between the total number of injury claims for injuries to the head and neck $\left(\chi^{2}=10, \mathrm{df}=5, \mathrm{p}=0.075\right)$, upper limbs $\left(\chi^{2}=24, \mathrm{df}=4\right)$, lower limbs $\left(\chi^{2}=237, \mathrm{df}=5\right)$ and chest and back $\left(\chi^{2}=41, \mathrm{df}=4\right)$ for female rugby league players. There was also a twofold increase in injury risk for the lower limb when compared with the upper limb (relative risk (RR) 1.94 (95\% CI 1.64 to 2.30)) while the head and neck (RR 3.85 (95\% CI 2.99 to 4.96$)$ ) and chest, back and other (RR 7.70 (95\% CI 5.33 to 11.3)) had an even higher risk of injury. The knee was the most commonly recorded injury site followed by the ankle, shoulder and lower leg (see table 6 ). The lower limb recorded $65 \%$ of the total female injury claims and $58.7 \%$ of total injury entitlement costs (\$922 296 ( $£ 356968)$ ). The mean cost per injury entitlement claim was higher for the lower $(\$ 4434$ (£1714)) than the upper (\$3331 (£1288)) limb. The highest injury site mean cost per injury entitlement claim was recorded for the head (except face) (\$7033 (£2724)), whereas that for the shoulder, (\$5746 (£2223)) knee (\$5568 (£2154)) and ankle (\$4317 (£1670)) was less.

\section{Female injury claims and costs by occupational group}

There were significant differences in the number of injury claims recorded for all occupational groups $\left(\chi^{2}=107, \mathrm{df}=8\right)$ (see table 7). Although female clerks are reported as comprising $9.8 \%$ of the total workforce, they recorded $16.3 \%$ of the total injury claims (162 per 1000 injury claims), 20.3\% of total injury costs (\$319 474 ( $£ 123211)$ ) and had the highest mean cost per claim (\$6144 (£2370)) (see table 6). Sales and service workers (workforce: $9.1 \%$; claims: $12.8 \%$; costs $10.5 \%$ ), technicians and associate professionals (workforce: $5.7 \%$ claims: $12.5 \%$; costs: $10.9 \%$ ) and plant and machinery operators and assemblers (workforce: $1.7 \%$; claims $10.9 \%$; costs: $12.3 \%$ ) recorded less.

\section{Female injury claims and costs by age}

The 25-29 age group recorded $31.9 \%$ of injury claims and $33.8 \%$ of injury costs (see table 8 ). This was slightly more than the $20-24$ age group (claims: $21.3 \%$; costs: $15.7 \% ; \chi^{2}=6, \mathrm{df}=1$ ) and the 30-34 age group (claims: $20.9 \%$; costs: $25.3 \% ; \chi^{2}=7$, $\mathrm{df}=1, \mathrm{p}=0.007)$. The $35-39$ age group recorded the highest mean cost per claim $(\$ 6200(£ 2392)$ ) but only $10.9 \%$ of total injury claims and $13.8 \%$ of total costs.

\section{DISCUSSION}

The ACC earnings-related compensations claims files that are lodged when an injury is seen by a healthcare provider is the only recording mechanism for rugby league injuries in New Zealand, although the data gathered through this system should not be seen as reflective of the total injury incidence of female rugby league participants. ${ }^{26}$ The results could be biased because they exclude female rugby league participants who do not make injury claims for more minor injuries. ${ }^{26}$ However, these results highlight the number of injuries over an 8-year recording period that were severe enough to require medical reporting. Because there was no participation, training or match-related data, comparisons between costs of injury claims and training and match exposure time could not be undertaken. There was no indication whether the injury claims recorded were for new or recurrent injuries or an exacerbation of a previous injury. The mean cost per claim ( $\$ 4913$ (£1872)) was greater than the mean ( $£ 467$ (\$1257)), median direct $(£ 28(\$ 76))$ or median indirect ( $£ 77(\$ 207))$ costs per playing injury previously reported ${ }^{15}$ but similar to the mean costs reported by King et al. ${ }^{27}$ This difference may be reflective of the limitations of previous studies identified by Gabbett. ${ }^{15}$

The actual number of participants in rugby league activities is unknown because there is currently no recording system in New Zealand for this information. One study ${ }^{20}$ reported that the total number of rugby league participants in New Zealand in 2005 was 21000 and that this has decreased to 16728 in $2009 .{ }^{28}$ This included junior, amateur male, female and masters participants. Unfortunately, there is no breakdown on the playing numbers at the different participation levels and the number of females participating in rugby league in New Zealand remains unknown. Despite this, the aim of this study was to identify the number and circumstance of women's injury claims and associated costs that occurred from participating in rugby league activities in New Zealand over an 8-year period. Unfortunately, there is a paucity of studies looking at injuries from participation in women's rugby league with which to compare these results.

Table 5 Total injury rate per 1000 entitlement claims with $95 \% \mathrm{Cl}$ and percentage of total claims and differences per year by injury type from 1999 to 2007

\begin{tabular}{|c|c|c|c|c|c|c|c|c|c|}
\hline & \multicolumn{2}{|c|}{ Total female injury claims } & \multicolumn{3}{|c|}{ Total female injury costs } & \multicolumn{2}{|c|}{$\begin{array}{l}\text { Difference over reporting } \\
\text { years for total injury claims }\end{array}$} & \multicolumn{2}{|c|}{$\begin{array}{l}\text { Difference between } 1999-2000 \text { and } \\
2006-2007 \text { for total injury claims }\end{array}$} \\
\hline & No. & Rate $(95 \% \mathrm{CI})$ & $\$(000)$ & $\%$ & Mean \$ & $\chi^{2}(\mathrm{df}=7)$ & p Value & $\chi^{2}(\mathrm{df}=1)$ & p Value \\
\hline Soft tissue injuries & 171 & 534.4 (460.0 to 620.8 ) & 848 & 53.9 & 4960 & 13 & 0.07 & 1 & 0.267 \\
\hline Fracture/dislocations & 118 & 368.8 (307.9 to 441.7$)$ & 500 & 31.8 & 4237 & 7 & 0.36 & 0.1 & 0.746 \\
\hline Other/unknown & 20 & 62.5 (40.3 to 96.9$)$ & 112 & 7.1 & 5587 & 9 & 0.197 & 3 & 0.083 \\
\hline Concussion/brain injury & 4 & 12.5 (4.7 to 33.3$)$ & 84 & 5.4 & 21100 & 12 & 0.101 & 0 & 1.0 \\
\hline Lacerations/puncture/wounds & 4 & 12.5 (4.7 to 33.3$)$ & 25 & 1.6 & 6221 & 12 & 0.101 & 0 & 1.0 \\
\hline Deafness & 3 & $9.4(3.0$ to 29.1$)$ & 3 & 0.2 & 993 & 21 & 0.004 & 0 & 1.0 \\
\hline Dental injuries & 0 & $0.0-$ & - & 0.0 & - & - & & - & \\
\hline Foreign body in orifice/eye & 0 & $0.0-$ & - & 0.0 & - & - & & - & \\
\hline
\end{tabular}

Rates are per 1000 injury claims. Percentage totals do not equal $100 \%$ because of data rounding. Total injury costs, percentage of total costs and mean cost per claim by injury type from 1999 to 2007. 
Table 6 Total injury rate per 1000 entitlement claims with $95 \% \mathrm{Cl}$ and percentage of total claims and differences per year by sex and injury site from 1999 to 2007

\begin{tabular}{|c|c|c|c|c|c|c|c|c|c|}
\hline & \multicolumn{2}{|c|}{ Total female injury claims } & \multicolumn{3}{|c|}{ Total female injury costs } & \multicolumn{2}{|c|}{ Difference over reporting years } & \multicolumn{2}{|c|}{ Difference 99-00 and 06-07 } \\
\hline & No & Rate $(95 \% \mathrm{Cl})$ & $\$(000)$ & $\%$ & Mean \$ & $\chi^{2}(\mathrm{df}=7)$ & p Value & $\chi^{2}(\mathrm{df}=1)$ & p Value \\
\hline Head and neck & 23 & $71.9(47.8$ to 108.2$)$ & 155 & 9.9 & 6743 & 36 & $<0.001$ & 1 & 0.273 \\
\hline Neck, back of head & 8 & $25.0(12.5$ to 50.0$)$ & 34 & 2.1 & 4206 & 9 & 0.253 & 0 & 1.0 \\
\hline Face & 2 & $6.3(1.6$ to 25.0$)$ & 3 & 0.2 & 1338 & 18 & 0.012 & 0 & 1.0 \\
\hline Eye & 3 & 9.4 (3.0 to 29.1$)$ & 13 & 0.8 & 4355 & 15 & 0.036 & 0 & 1.0 \\
\hline Upper limb & 71 & $221.9(175.8$ to 280.0$)$ & 356 & 22.7 & 5020 & 8 & 0.327 & 0 & 0.862 \\
\hline Shoulder & 39 & $121.9(89.0$ to 166.8$)$ & 230 & 14.6 & 5894 & 3 & 0.843 & 0.1 & 0.763 \\
\hline Upper and lower arm & 14 & $43.8(25.9$ to 73.9$)$ & 47 & 3 & 3330 & 3 & 0.885 & 0 & 1.0 \\
\hline Elbow & 3 & 9.4 (3.0 to 29.1$)$ & 7 & 0.4 & 2313 & 15 & 0.036 & 3 & 0.083 \\
\hline Hand/wrist & 6 & 18.8 (8.4 to 41.7$)$ & 40 & 2.5 & 6673 & 6 & 0.54 & 0 & 1.0 \\
\hline Finger/thumb & 9 & 28.1 (14.6 to 54.1$)$ & 33 & 2.1 & 3663 & 6 & 0.463 & 0.1 & 0.706 \\
\hline Lower leg & 16 & $50.0(30.6$ to 81.6$)$ & 66 & 4.2 & 4116 & 4 & 0.78 & 0 & 1.0 \\
\hline Ankle & 49 & 153.1 (115.7 to 202.6) & 220 & 14 & 4493 & 5 & 0.584 & 1 & 0.248 \\
\hline Foot & 15 & 46.9 (28.3 to 77.8$)$ & 14 & 0.9 & 905 & 9 & 0.253 & 0 & 1.0 \\
\hline Toes & 3 & $9.4(3.0$ to 29.1$)$ & $<0.5$ & 0 & 57 & 21 & 0.004 & 3 & 0.083 \\
\hline Chest, back, other & 9 & 28.1 (14.6 to 54.1$)$ & 29 & 1.9 & 3238 & 18 & 0.011 & 0 & 1.0 \\
\hline Chest & 4 & 12.5 (4.7 to 33.3$)$ & 3 & 0.2 & 740 & 12 & 0.101 & 0 & 1.0 \\
\hline Back/spine & 5 & $15.6(6.5$ to 37.5$)$ & 26 & 1.7 & 5236 & 9 & 0.253 & 0 & 1.0 \\
\hline Abdomen/pelvis & 0 & $0.0_{-}$ & - & 0.0 & - & - & & - & \\
\hline Internal organs & 0 & $0.0_{-}$ & - & 0.0 & - & - & & - & \\
\hline Multiple injuries & 0 & $0.0_{-}$ & - & 0.0 & - & - & & - & \\
\hline Unknown & 22 & 68.8 (45.3 to 104.4 ) & 109 & 6.9 & 4962 & 0.2 & 0.999 & 0 & 1 \\
\hline
\end{tabular}

Rates are per 1000 injury claims. Total injury costs, percentage of total costs and mean cost per claim by sex and injury site from 1999 to 2007.

Table 7 Percentage of total female population by occupational group and by total workforce

\begin{tabular}{|c|c|c|c|c|c|c|c|c|c|}
\hline & \multicolumn{2}{|c|}{ Females by consensus ${ }^{21}$} & \multicolumn{2}{|c|}{ Total female injury claims } & \multicolumn{3}{|c|}{ Total female injury costs } & \multicolumn{2}{|c|}{$\begin{array}{l}\text { Difference over } \\
\text { reporting years }\end{array}$} \\
\hline Unknown & 4.3 & 0.2 & 84 & 262.5 (212.0 to 325.1$)$ & 363 & 23.1 & 4321 & 7 & 0.386 \\
\hline Clerks & 78.2 & 9.8 & 52 & 162.5 (123.8 to 213.3$)$ & 319 & 20.3 & 6144 & 1 & 0.968 \\
\hline Technicians and associate professionals & 51.6 & 5.7 & 39 & 121.9 (89.0 to 166.8$)$ & 171 & 10.9 & 4378 & 7 & 0.409 \\
\hline Service and sales workers & 64.6 & 9.1 & 37 & 115.6 (83.8 to 159.6$)$ & 165 & 10.5 & 4453 & 4 & 0.684 \\
\hline Legislators, administrators and managers & 39.5 & 5.0 & 18 & $56.3(35.4$ to 89.3$)$ & 94 & 6 & 5218 & 0.2 & 0.999 \\
\hline Professionals & 55.7 & 7.7 & 13 & $40.6(23.6$ to 70.0$)$ & 62 & 3.9 & 4760 & 11 & 0.111 \\
\hline Trades workers & 5.8 & 0.5 & 10 & 31.3 (16.8 to 58.1$)$ & 68 & 4.3 & 6826 & 18 & 0.012 \\
\hline
\end{tabular}

Rates are per 1000 injury claims. Total injury rates per 1000 entitlement claims with $95 \% \mathrm{Cl}$ and percentage of total claims and differences per year by occupational group from 1999 to 2007. Total injury costs, percentage of total costs and mean cost per claim by occupational group from 1999 to 2007.

Apart from the likelihood of their being fewer women rugby league players, when compared with other studies in rugby league injuries, it appears that females (5.7\%) incur fewer injuries in rugby league than males (94.3\%). ${ }^{27} \mathrm{~A}$ possible hypothesis for this low number of injury claims is that females participate in contact sport with less aggressiveness than males. This has been previously suggested and investigated for all women's sports and the results identified that there are sex similarities in the attitudes of athletes in areas such as aggression, physical danger and injury. ${ }^{29}$ Women athletes have demonstrated that they are as willing as males to expose themselves to physical risk, injury and aggression. ${ }^{29}$ Another suggestion for the difference in the injury incidence is the differences in the physicality and speed of female players when compared to male players. Gabbett's ${ }^{10}$ study on elite female rugby league players reported that they had a slower speed and agility, lower muscular power, lower estimated maximal aerobic power and a greater body mass and skinfold thickness than male participants. A third possible difference may be there are less women playing rugby league in New Zealand when compared to male rugby league participation. However, there are no available participation data to enable a comparison to be undertaken. 
Table 8 Total injury rate per 1000 entitlement claims with 95\% Cl and percentage of total claims and differences per year by age from 1999 to 2007

\begin{tabular}{|c|c|c|c|c|c|c|c|c|c|}
\hline Age & \multicolumn{2}{|c|}{ Total female injury claims } & \multicolumn{3}{|c|}{ Total female injury costs } & \multicolumn{2}{|c|}{ Difference over reporting years } & \multicolumn{2}{|c|}{$\begin{array}{l}\text { Difference between 1999-2000 } \\
\text { and 2006-2007 }\end{array}$} \\
\hline $5-9$ & 0 & $0-$ & & 0 & - & - & & - & \\
\hline $15-19$ & 32 & $75.0(50.3$ to 111.9$)$ & 97 & 6.1 & 4021 & 5 & 0.599 & 0.1 & 0.706 \\
\hline $20-24$ & 68 & 212.5 (167.5 to 269.5$)$ & 247 & 15.7 & 3637 & 8 & 0.333 & 0.0 & 0.848 \\
\hline $25-29$ & 102 & $318.8(262.5$ to 387.0$)$ & 532 & 33.8 & 5213 & 9 & 0.227 & 0.0 & 0.853 \\
\hline $35-39$ & 35 & $96.9(68.1$ to 137.8$)$ & 217 & 13.8 & 7001 & 6 & 0.497 & 0.1 & 0.739 \\
\hline $40-44$ & 18 & $31.3(16.8$ to 58.1$)$ & 53 & 3.4 & 5311 & 6 & 0.540 & 0 & 1.0 \\
\hline $45-49$ & 6 & $18.8(8.4$ to 41.7$)$ & 10 & 0.6 & 1617 & 18 & 0.012 & 3 & 0.083 \\
\hline $50-54$ & 9 & 28.1 (14.6 to 54.1 ) & 11 & 0.7 & 1269 & 15 & 0.036 & 3 & 0.083 \\
\hline $55-59$ & 0 & $0.0_{-}$ & - & 0.0 & - & - & & - & \\
\hline $60-64$ & 0 & $0.0_{-}$ & - & 0.0 & - & - & & - & \\
\hline
\end{tabular}

Rates are per 1000 injury claims. Percentage totals do not equal $100 \%$ because of data rounding. Total injury costs, percentage of total costs and mean cost per claim by age from 1999 to 2007.

Not every district in New Zealand has women participating in rugby league activities. Some districts have only recently begun women's rugby league competitions, whereas some districts only participate in national tournaments. It appears that the history of the establishment of women's rugby league in New Zealand is similar to other countries ${ }^{11}$ and has been left to a few people motivated to support and administer the game in the different districts. Matches are typically held on a Sunday and some participants reportedly participate in other sporting activities before the matches on Sundays. This may result in players carrying unresolved injuries into the match resulting in a higher injury entitlement claim incidence.

National tournaments for women's rugby league are typically held annually for the selection of the New Zealand representative team, the "Kiwi Ferns". These tournament formats can vary from a weekly home-and-away competition to teams from several districts gathering in one location and participating in several matches held over a short period. ${ }^{18}$ The recognition of the importance for selection in the national team to participate in international competitions may be reflected in the incidence over the years as shown in table 2. The Women's Rugby League World Cup was held in 2000,2005 and then again in 2008. The incidence of injury claims was higher in the 1999-2000 reporting period than in the following 4 years before it again rose in the later part of the study period reflecting the periods surrounding the World Cup competitions. More detailed epidemiological studies need to be undertaken to identify if there is any correlation between the number of female participants and the international women competitions that occur.

Although the incidence of injury claims for concussions (37 per 1000) was higher than the injury rate reported for total injury claims (18 per 1000), ${ }^{19}$ the percentage of costs for these claims was similar $\left(5 \%\right.$ vs $\left.6 \%{ }^{19}\right)$. As a result, the mean cost per injury claim for concussions was the highest of all the injury type mean costs. This difference may be reflective of other studies reporting that females were more likely to report concussions than males. ${ }^{30}$ Suggested factors for this may be biological differences, sex bias, socialization and social roles that females undertake. ${ }^{31}$ Other research has suggested female athletes may be at an increased risk of incurring a concussion due to smaller size and weaker neck muscles when compared to male athletes, ${ }^{32}$ and this is an area that warrants further research in all female sporting activities.

The percentage of lower limb injuries (65\%) recorded in this study was similar to that recorded for women's rugby union $\left(44 \%^{33}, 46 \%^{34}, 52 \%^{35}\right.$ and $\left.66 \%^{36}\right)$ and rugby league ${ }^{18}$ $(55 \%)$ but higher than the total MSCs (42\%). ${ }^{19}$ The percentage of costs (59\%) recorded in this study for lower limb injury claims was proportionally higher than that reported for all MSCs (32\%). ${ }^{19}$ Lower limb injuries are common in many sporting activities ${ }^{37}$ and females are reported to be almost twice as likely to sustain an injury to this area when compared to males. ${ }^{38}$ The high-frequency (65\%) and cost proportion (58.7\%) for lower limb injuries were higher in our study for females than in male rugby league players (previously reported as $42.4 \%$ of the injury claims and $31.5 \%$ of the total injury claim costs for the lower limb). Studies ${ }^{19}$ have also reported that although sex discrepancies for lower limb injuries are not fully understood, lower limb kinematics during running may be a contributing factor. ${ }^{38}$ Sex-specific morphology of the pelvis and thigh may also contribute to the differences identified when running. ${ }^{38}$ With the differences in lower limb kinematics, there is the possibility that female lower limbs attain maximum muscular limits faster when running than males and are possibly more susceptible to the onset of fatigue effects. ${ }^{38}$ Studies involving fatigue have identified that kinematic adjustments do occur when the muscle is exhausted ${ }^{39}$ and that there is an increased risk of a running-related injury occurring as a result of these changes. ${ }^{40}$ Further research is warranted to see whether injury reduction programs such as weight and strength training of the lower limbs and lower back and preseason fitness development can assist in the reduction of injuries to the lower limb in women's rugby league participants.

\section{CONCLUSIONS}

This study has reported the lacuna of information in regards to the costs and incidence of injury claims for women rugby 
league participants. Although it is important in understanding the costs incurred and how injuries were sustained across injury sites, injury types, age categories and regions in the country, the data do not provide information on (1) how the injuries occurred, (2) whether they occurred as a result of match or training activities, nor (3) at what stage of the match the injuries occurred. The need for further studies into women's rugby league injuries is therefore warranted to enable identification of the incidence, site and type of injuries that occur from participation in rugby league activities and to assist in understanding the types of injuries that can occur for women. The results of these studies can assist in tailoring injury prevention programs towards women participants and will assist in covering the lacuna of data on women's rugby league injuries. Initial injury prevention programmes should focus on the 25-29 age group and address ways to prevent concussion and lower limb injuries.

\section{Competing interests None.}

Ethics approval This study was conducted with the approval of the Auckland University of Technology Ethics Committee.

Provenance and peer review Not commissioned; externally peer reviewed.

\section{What is already known on this topic}

- There is scarce information on rugby league injuries in female players despite domestic, national and international competitions being played.

\section{What this study adds}

- There were 320 moderate to serious injuries for female rugby league players over the 8 years giving a mean (SD) of 37.9 (9.5) injury claims per year and \$196 514 (\$99 133) (£76 066 (£38 374)) cost per year. The lower limb accounted for $65 \%$ of the total female injury claims and $58.7 \%$ of total injury costs (\$922 296 ( $\mathrm{f356} 968$ )). The $25-29$ age group recorded $31.9 \%$ of injury claims and $33.8 \%$ of injury costs. Concussion/brain injuries had the highest mean cost per claim (\$7033 (f2724)). Injury prevention programmes for women's rugby league should focus on the 25-29 age group and address ways to prevent concussion and lower limb injuries.

\section{REFERENCES}

1. Gabbett TJ. Science of rugby league football: a review. J Sports Sci 2005:23:961-76

2. Gabbett TJ. Incidence of injury in amateur rugby league sevens. Br J Sports Med 2002;36:23-6.

3. Gabbett TJ. Incidence of injury in junior and senior rugby league players. Sports Med 2004;34:849-59.

4. Gabbett TJ. Incidence, site, and nature of injuries in amateur rugby league over three consecutive seasons. Br J Sports Med 2000;34:98-103.

5. King DA, Gabbett TJ, Dreyer C, et al. Incidence of injuries in the New Zealand national rugby league sevens tournament. J Sci Med Sport 2006;9:110-18.

6. Seward H, Orchard J, Hazard H, et al. Football injuries in Australia at the élite level. Med J Aust 1993;159:298-301.

7. Stephenson $\mathbf{S}$, Gissane $C$, Jennings $D$. Injury in rugby league: a four year prospective survey. Br J Sports Med 1996;30:331-4.
8. Phillips LH, Standen PJ, Batt ME. Effects of seasonal change in rugby league on the incidence of injury. Br J Sports Med 1998;32:144-8.

9. Meir R, Colla P, Milligan C. Impact of the 10 meter rule change on professional rugby league: implications for training. Strength Cond J 2001;23:42-6.

10. Gabbett TJ. Physiological and anthropometric characteristics of elite women rugby league players. J Strength Cond Res 2007;21:875-81.

11. Little C. 'What a freak-show they made!' Women's rugby league in 1920 s Sydney. Foot Stud 2001;4:25-40.

12. Gabbett TJ. Incidence of injury in junior rugby league players over four competitive seasons. J Sci Med Sport 2008;11:323-8.

13. Raftery M, Parker R, Stacey E, Peat J, Wang H. Incidence of injury in junior rugby league in the Penrith and district rugby league area. Children's Hospital Institute of Sports Medicine. Westmead: Research and Development Office, The New Children's Hospital, 1999.

14. Gabbett TJ. Incidence of injury in semi-professional rugby league players. $\mathrm{Br} \mathrm{J}$ Sports Med 2003;37:36-43; discussion 43-4.

15. Gabbett TJ. Severity and cost of injuries in amateur rugby league: a case study. J Sports Sci 2001;19:341-7.

16. Walker RD. Sports injuries: rugby league may be less dangerous than union. Practitioner 1985;229:205-6.

17. King DA, Gabbett TJ, Gissane C, et al. Epidemiological studies of injuries in rugby league: suggestions for definitions, data collection and reporting methods. J Sci Med Sport 2009;12:12-9.

18. King DA, Gabbett TJ. Injuries in a national women's rugby league tournament: an initial investigation. NZ J Sports Med 2007;34:18-22.

19. King D, Hume PA, Milburn PD, Gianotti S. Rugby league injuries in New Zealand: a review of eight years of Accident Compensation Corporation injury entitlement claims and costs. Br J Sports Med. 2009;43:595-602

20. Gianotti S, Hume PA. A cost-outcome approach to pre and post-implementation of national sports injury prevention programmes. J Sci Med Sport 2007; 10:436-46

21. Statistics New Zealand. http://www.stats.govt.nz/census. 2006 (accessed 1 June 2008).

22. Hancock A. New Zealand standard classification of occupations. Wellington New Zealand: Statistics New Zealand, 1999

23. Gianotti SM, Marshall SW, Hume PA, et al. Incidence of anterior cruciate ligament injury and other knee ligament injuries: a national population-based study. J Sci Med Sport 2009;12:622-7.

24. Hodgson Phillips L. Sports injury incidence. Br J Sports Med 2000;34:133-6.

25. Twellaar $\mathbf{M}$, Verstappen FT, Huson A. Is prevention of sports injuries a realistic goal? A four-year prospective investigation of sports injuries among physical education students. Am J Sports Med 1996;24:528-34.

26. Lythe MA, Norton RN. Rugby league injuries in New Zealand. NZ J Sports Med 1992;20:6-7.

27. King DA, Hume PA, Milburn P, Gianotti S. Rugby league injuries in New Zealand variations in injury claims and costs by ethnicity, gender, age, district, body site, injury type and occupation. NZ J Sports Med. 2009;36:48-55

28. Anderson J. Rugby league-contributing to New Zealand's future. Report of the independent review committee. Sport and Recreation New Zealand, 2009.

29. Young K, White P. Sport, physical danger, and injury: the experiences of elite women athletes. J Sport Soc /ssues 1995;19:45-61.

30. Bloom GA, Loughead TM, Shapcott EJB, Johnston KM, Delaney JS. The prevalence and recovery of concussed male and female collegiate athletes. Eur J Sport Sci 2008;8:295-303.

31. Barsky AJ, Peekna HM, Borus JF. Somatic symptom reporting in women and men. J Gen Intern Med 2001;16:266-75.

32. Carson JD, Roberts MA, White AL. The epidemiology of women's rugby injuries. Clin J Sport Med 1999;9:75-8

33. Schick DM, Molloy MG, Wiley JP. Injuries during the 2006 Women's Rugby World Cup. Br J Sports Med 2008;42:447-51.

34. Carson JD, Roberts MA, White AL. The epidemiology of women's rugby injuries. Clin J Sport Med 1999;9:75-8.

35. Comstock RD, Fields SK. The fair sex? Foul play among female rugby players J Sci Med Sport 2005;8:101-10.

36. Doyle C, George K. Injuries associated with elite participation in women's rugby over a competitive season: an initial investigation. Phys Ther Sport 2004;5:44-50

37. Twomey D, Finch C, Roediger E, et al. Preventing lower limb injuries: is the latest evidence being translated into the football field? J Sci Med Sport 2009;12:452-6.

38. Chumanov ES, Wall-Scheffler C, Heiderscheit BC. Gender differences in walking and running on level and inclined surfaces. Clin Biomech (Bristol, Avon) 2008;23:1260-8

39. Derrick TR, Dereu D, McLean SP. Impacts and kinematic adjustments during an exhaustive run. Med Sci Sports Exerc 2002;34:998-1002.

40. Gabbett TJ. Influence of training and match intensity on injuries in rugby league. J Sports Sci 2004;22:409-17. 